Triangle Open Scholarship

\title{
A Response to the Call for Bibliodiversity: Language, Translation, and Communicated Scholarship
}

\section{Allison Kittinger ${ }^{1}$, Micah Vandegrift ${ }^{2}$}

${ }^{1}$ University of North Carolina - Chapel Hill, ${ }^{2}$ North Carolina State University

Published on: Aug 28, 2020

DOI: $10.21428 / 3 d 640 a 4 a .48 e a 4 b 20$

License: Creative Commons Attribution 4.0 International License (CC-BY 4.0). 


\section{Contributor statement}

We utilized the CRediT taxonomy to describe the labor of each individual, understanding that the definitions are not all encompassing of the collaborative nature of this work.

- Allison Kittinger performed investigation and wrote the original draft.

- Micah Vandegrift provided_project administration, supervision, and reviewed and edited the work.

- Will Cross was instrumental in the conceptualization and methodology of the research project.

\section{Introduction}

This paper is the product of a research study conducted over the summer of 2020 at North Carolina State University's Copyright and Digital Scholarship Center. The purpose of this study was to investigate a response to recent calls for increased bibliodiversity and multilingualism in scholarly communications. Over the course of developing this paper, members of the local scholarly publishing and public science communication communities were interviewed for their thoughts on bibliodiversity and its impacts on scholarly communications. 


\section{Bibliodiversity}

The term bibliodiversity appeared originally in Spanish as

bibliodiversidad $\underline{1}$, and referred to diversity of book publishing platforms and formats (print, digital, oral, etc.). The concept of bibliodiversity is now being adapted for the contemporary scholarly communications landscape, emphasizing the importance of "diversity in services and platforms, funding mechanisms, and evaluation measures."[1] If the scholarly communications community widely embraces bibliodiversity, Shearer et al. write, the way would be paved for

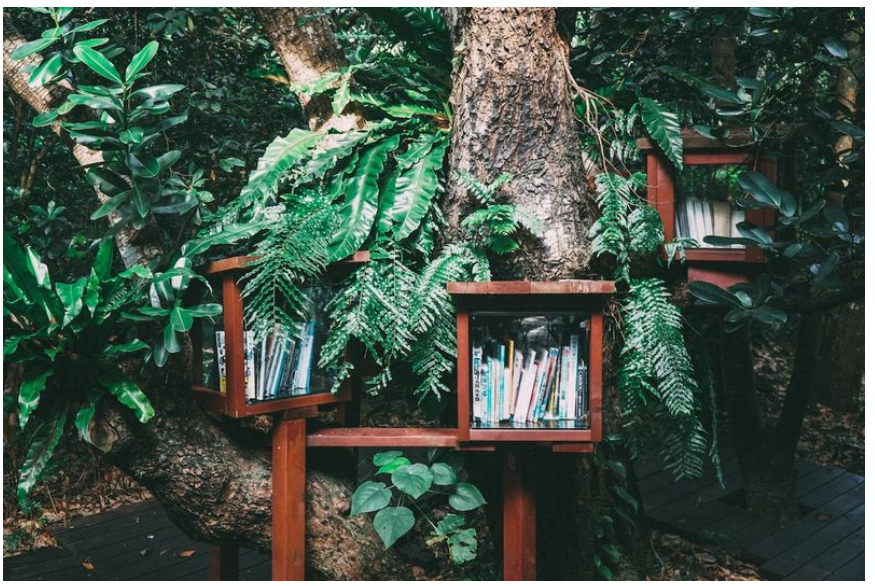
Image from Hitoshi Suzuki via Unsplash (Licensed under a CCO 1.0 license), as discovered from the London School of Economics - Impact of Social Sciences blog post titled "Bibliodiversity_ - What it is and why it is essential to creating situated knowledge." "the scholarly communication system to accommodate the different workflows, languages, publication outputs, and research topics that support the needs and epistemic pluralism of different research communities."

In scholarly communications, bibliodiversity is predicated on - and leads to - openness in scholarly processes and outputs. The Jussieu Call for Open Science and Bibliodiversity argues that the ability of a small number of traditional Western scholarly publishers to influence the viability of open access models is antithetical to bibliodiversity. The coexistence of scholarly publishing models beyond the traditional Western one - models that are open and accessible to a greater number of researchers and the community - will in turn open up space for the coexistence of voices and epistemologies historically excluded from scholarly conversations. The term "mosaic epistemology," described by Connell in the field of sociology as "a clear alternative to northern hegemony and global inequality, replacing the priority of one knowledge system with respectful relations among many,"[ㄹ] was adapted by Chan et al.[ㅁ] ] as a foundation for open science. Bibliodiversity and openness are crucially dependent on each other to achieve the mutual goal of diversity, equity, and inclusion in scholarly publishing; their relationship is symbiotic in that more of one opens the door for more 
of the other. The best example we have to point to so far is the growth and diversity of pre-print archives, especially InaArxiv, $\underline{\text { AfricArxiv, }}$ and FrenXiv.

However, it is important to emphasize the fact that greater bibliodiversity and open access adoption in scholarly communications will not automatically achieve this goal. Intentional steps must be taken to employ equitable methods of publishing and dissemination, and to avoid perpetuating the uneven power structures and hierarchies of the current research landscape. Many have noted the importance of interrogating boundaries of scholarly communities in doing this work. Chan et al., for example, present two questions as crucial to any open science initiative: "whose open science?" and "for whom is science being opened?"[4] These questions recognize that openness is situated and dependent on the actors in a given context. Scholarly communities and their labels are also situated, as Golumbia illustrates in the field of digital humanities. He notes that many communities practicing digital humanities outside of Western, majority-white, majority-male digital humanities institutions do not use the label "digital humanities" to describe their work, but there is danger of perpetuating the centrality of those institutions when they are given the power to dole out that label: "this is one of the deep cruxes that DH as a label has created for itself-it needs this material in order to de-colonize itself, but taking that material in looks like a colonizing gesture, one that is meant to benefit "us" much more than "them." [ㅁ] This raises the question that Galina asks about the digital humanities community: "who is we?"[ㅁ]

Hathcock makes similar observations about the scholarly communications community. She recalls one of her colleagues from Egypt telling her that "the term "open access" has no direct translation in Arabic and that the concept varies depending on culture and country." She also observed the majority of attendees at a scholarly communications conference leave the main room to attend a "fringe" topic pertaining to building a scholarly commons in the global south, noting that "because it was not a priority for the white, colonial scholarly commons agenda, it was relegated, literally and physically, to the margins, ghettoized from the main discourse."[7] To reform and decolonize scholarly communications, Hathcock writes, "The conversation needs to be an actual conversation and not a one-way soliloquy from the global north that gets imported colonial-style to the global south. There needs to be a dialogue, real dialogue, that decenters white North American and Western European values and knowledge creation." 


\section{Multilingualism}

With this in mind, another question emerges: in what language(s) will this dialogue be carried out? Recent calls for increased multilingualism in research and scholarly communications highlight the current state of English monolingualism in research. The introduction to the Helsinki Initiative on Multilingualism in Scholarly_ Communication is particularly illustrative:

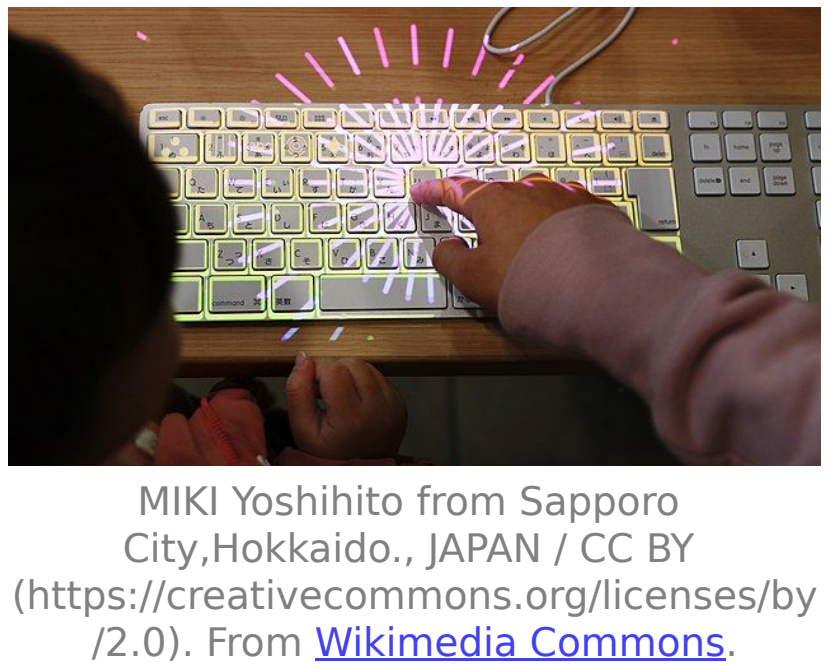

"Research is international. That's the way we like it! Multilingualism keeps locally relevant research alive. Protect it! Disseminating research results in your own language creates impact. Endorse it! It is vital to interact with society and share knowledge beyond academia. Promote it! Infrastructure of scholarly communication in national languages is fragile. Don't lose it!"[ㅇ]

From the implied inverse of these statements, one can infer that English monolingualism in scholarly communications dismisses multilingual research as irrelevant, hinders the dissemination of research into local communities outside of academia, and discourages the creation of infrastructure supporting publication in other languages. Currently, the boundaries of many scholarly communities are in part drawn with language. Hathcock writes that "I learned from my Latin American colleagues that they are essentially forced to cite North American or Western European researchers in all their work in order to get published, even if/when they have fellow Latin American colleagues whose work is more on point."[ㅁ] Ezema and Onyancha in describing Africa's knowledge economy observe that "scientific publications in African languages are often considered as strange to the global scholarly community and consequently observations have shown that they are rarely indexed by major databases such as Thomson Reuters, Scopus, Medline and Google

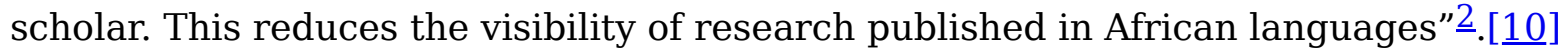
The disincentivizing of multilingual research described in these passages reinforces the colonizing notion that countries that do not produce research in English are not producing research at all and are merely consumers of Western knowledge. 
In addition, English fluency is unfairly regarded as a measure of research quality and researcher reputation. As Dacos puts it, "If we adapt a sports metaphor, we could say that continental Europe, South America, Asia and Africa permanently play as visitors, while the Anglo-American world does so as a local; even $1000 \mathrm{~km}$ from their bases."[11] The OPERAS Multilingualism Working Group recognizes that "the choice of a language system often implies the choice of a frame of references, of a methodology, of a school. Therefore, the usage of a lingua franca implies for a non-native speaker not only an impoverishment of its expressive means, but it can also be misunderstood as closeness to a certain field of research." Because English monolingualism is inextricably tied to Western monoculture in scholarly communications, it is imperative that bibliodiversity efforts disrupt this monolingualism and make space for multilingual publications as well as multicultural research practices and publication models. Some of this work is being done through, one interviewee noted, an increased amount of research communication professional development opportunities such as workshops and instruction sessions. For example, Pelak and Rochen Renner mentioned in their 2020 Triangle Research Library_Network annual meeting presentation that UNCChapel Hill's strategy for teaching researchers about community-engaged research presentation includes cultural competency awareness.

\section{Linguistic landscapes}

To understand the extent to which English monolingualism is present in scholarly publishing, it would be instructive to take stock of the linguistic landscape of scholarly communications. The concept of the linguistic landscape was introduced into the field of linguistics by Landry and Bourhis, which they defined as "the visibility and salience of languages on public and commercial signs in a given territory or region".[12] Landry and Bourhis theorized that looking at how language is semiotically represented and publicized in public spaces could reveal insights about the relationships and power structures between linguistic communities in those spaces.

Although the field of study of linguistic landscapes is relatively new, it is rapidly expanding into new contexts. One of these is online spaces, which has given rise to the idea of the virtual linguistic landscape. Biró, for example, examines social media as a linguistic landscape, noting that although virtual linguistic landscapes differ from physical ones because they do not reflect real-world linguistic situations and communities, they can still reveal power structures, communication styles, and individual identity representation among participants in the virtual linguistic landscape. [13] Lvković also explores virtual linguistic landscapes through visiting various public 
online communities and studying how they represent and interact with languages. After visiting these sites, Lvković writes that even in virtual linguistic landscapes, "the linguistic choices are never neutral, rendering these objects indexical of ideologies and/or established norms".[14]

Applying linguistic landscapes models to scholarly communications could provide insight into the decisions behind the use of language. From indexes and metrics, to infrastructure, to websites, to conference signage, to language requirements for publication, there is a rich network of connected environments and spaces under the umbrella of scholarly communications filled with specific linguistic choices. Analyzing the linguistic landscapes in these spaces and the rationale for the choices behind them could help inform bibliodiversity and multilingualism policy in scholarly communities.

\section{Translation Landscapes}

Widespread dismantling of monolingualism in scholarly communications will take some translation work - but not only translation in the linguistic sense. There is also the more metaphorical act of translating scholarly work of, by, and for the public. This work is a necessary component of the bibliodiversity model because it expands the borders of the scholarly community, creates more opportunities for public involvement and the recognition of varying epistemologies and approaches, and enhances open science and open access initiatives.

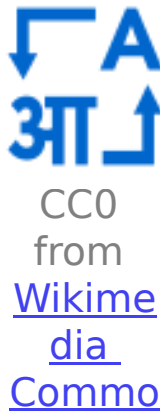

$\underline{\text { ns. }}$.

Because it is the Western scholarly communications institution that is currently hindering multilingualism and translation, change must be implemented at the institutional level. Opportunities for this change arise at mediating institutions between scholarly publishers and researchers: universities, academic libraries, and scholarly translation services. These are sites in which much of the current translation work is being done. At many universities, students and researchers are introduced to the idea of writing about scholarly topics for a public audience in classes and workshops. At UNC-Chapel Hill, for example, first-year English library instruction sessions introduce the difference between scholarly and popular sources, often to support assignments such as science podcasts that communicate scientific knowledge to the public. NC State University has offerings of public science and science communication courses. Additionally, many academic libraries perform translative acts in the development and production of digital research projects, adapting academic knowledge into online spaces, and new inviting forms of media. 
However, these institutions also perpetuate the current Western scholarly communications hegemony. For one, neither linguistic nor popular translation are consistently or systematically recognized as scholarly labor. The decisions to engage with the public or translate work into another language are most often left to individual researchers whose careers rest on operating with the dominant Western scholarly publishing model. This environment leaves no space for individual researchers to undertake this labor while receiving academic recognition for it. To shine a spotlight on this issue, Modern Languages Open published a manifesto on acknowledging translation work as scholarly activity so that it "matters for appointments, promotions and tenure."[15] Academic libraries, too, are participating in this hierarchy. Henninger writes that like the scholarly publishing industry, many libraries have engaged in the neoliberal commodification of language, which views "a particular language as a demand-driven commodity or a prerequisite for using library services."[16] That language is usually English.

Although more work needs to be done (especially when it comes to recognizing translation as scholarship), new and nontraditional forms of research communications are increasingly being recognized as scholarly labor. Visual forms of scholarship as well as scholarly blogs and podcasts geared toward a public audience are gaining traction as platforms for scholarship. Pelak and Rochen Renner, for example, emphasize the importance of graphics in communicating research to the public.[17] NC State University Libraries' deep investment in visualization as a communication/community activity is also widely regarded as an innovative approach to this challenge, evidenced in the Immersive Scholar project funded by a grant from the Andrew W. Mellon Foundation. We are particularly keen on the work of the Chancellor's Faculty Cluster for Visual Narratives at NC State as a multidisciplinary model and opportunity for advancement in this area. Visual representations and communications of research decentralize language choice, which in turn decentralizes English as the dominant mode of research communication.

\section{Voices from the Field}

We first spoke with Lindsay Miller of American Journal Experts (AJE), an author services company that provides scholarly translation, and Omar Fabian of Research Square, AJE's preprint platform. Miller stated that the goals of AJE are to help researchers succeed, erase language as a barrier, and address publishing for researchers whose first language is not English. They use a combination of machine and human translation in the editing process to ensure quality. With Research Square, 
one of the goals is to allow research to be disseminated as quickly and safely as possible with a quality control process. Machine translation is one method for reducing the labor around translating scholarly work, although it still requires human quality control.

AJE and Research Square also work to cater to the public by tailoring products. As part of their services, they offer lay summaries designed to convey findings and limitations to the public. They maintain channels of community governance through preprints and social media, and they are working on diversifying research signifiers. All of this work contributes to increased public engagement and bibliodiversity in the scholarly community.

We next spoke to Jennifer Landin, a Teaching Associate Professor in biology at North Carolina State University. She emphasized that it is the responsibility of science communicators to convey research and knowledge clearly and effectively, not the public's responsibility to work to understand it. She considers that the tenure process may reward advanced approaches and technical language, which distances research from the public. As Kathleen Fitzpatrick writes, "The problem, of course, is that the more we close our work away from the public, and the more we refuse to engage in dialogue with them, the more we undermine that public's willingness to fund our research and our institutions. Closing our work away from the public, and keeping our scholarly conversations private, might protect us from public criticism, but it can't protect us from public apathy, a condition that is, in the current economy, far more dangerous." $[\underline{18}]$

In the current science communications economy, Landin made a distinction between "true diversity" (bibliodiversity) and "false diversity" in publishing. She defined "false diversity" as many people copying the same information, which is more damaging than uniformity because it gives a false sense of credibility or normalization to a single widely copied approach. She gave the example of online textbooks merely rewording existing texts because there is little to no financial benefit in creating a new textbook. She concluded with the idea that small, more nimble publishers have the potential to be disruptors in this space.

A third interviewee agreed that messaging is the responsibility of research communicators, and that diversity in modes of communications meet the public where they are in terms of background, where they find information, education levels, etc., improving exposure and understanding of different research findings. This interviewee pointed out that while bibliodiversity can increase types and levels of knowledge in 
science, it could also make it harder to control truth vs. perception (a "natural evolution" within emerging fields, as the interviewee characterized it), which could in turn play into difficult discussions about placing trust in the expertise of the academy. As more people contribute to the emerging field, it will become organized and contextualized after the fact.

\section{Conclusions}

Through our brief study, it appears that there are activities underway to increase bibliodiversity, multilingualism, and open access in scholarly communications, but these efforts are not yet standardized or mainstreamed as part of the scholarly publishing process. More work needs to be done to incentivize open publishing, new forms of scholarship, public engagement, and translation to make space for more languages and cultural perspectives within the research landscape. Such incentives could take the form of acknowledging this work by including it in promotion and tenure or publisher policies, or for funders to invest in studies on and/or production of bibliodiverse, open knowledge. Professional development in research communications for researchers should also emphasize awareness of public engagement with research and situated languages and cultural perspectives.

In the field of digital humanities, Golumbia recommends the following for promoting multilingualism:

- "Increased attention from digital humanists to the world's minority languages;

- An increased focused on language revitalization projects as inherently a part of DH;

- Increased recognition of the importance of speaking to language itself, and support for projects that take spoken language as the evidentiary base from which to proceed;

- Support from DH funding bodies for work like the World Oral Literature Project, the Wikimedia Oral Citations project, and even the World Atlas of Linguistic Structures;

- Careful thought and even elaboration of the postcolonial studies perspective on all media and technology interactions with indigenous peoples;

- Significant work within the majority digital realm to combat the pernicious stereotypes of indigenous peoples and their languages."[19]

Publishers and universities could intentionally set aside resources to initiate or support projects that promote multilingualism. These ideas could also be applied to other disciplines. Researchers can also decentralize the dominant white Western perspective 
in research and publishing by intentionally stating their positionality in relation to their research.

Libraries, long a partner in communicating scholarly knowledge to the public, should also look at their positionality and the culture of language choice within their walls. Are languages of communication within the library chosen for their perceived "value?" Or do they reflect the community and the collections? Answering these questions will make libraries better equipped to offer advice on research communications.

Examples of emerging and alternative forms of scholarship (insofar as they are rendered alternative) created by researchers and the public are plentiful but decentralized. This work could be made available in the form of a database or collection based on the local community and its needs, or developed in partnership with the community. For example, Jennifer Landin also expressed a desire for a centralized science communications database because the field is so interdisciplinary and it is difficult to find isolating keywords for it.

There is no one-size-fits all answer to calls for bibliodiversity and multilingualism. As Chan et al. write, "knowledge production and dissemination is situated within particular historical, political, socio-cultural, and legal relations."[]ㅡ Context varies from institution to institution and from community to community, and what might be a valid solution for one situation in North America will be meaningless for another in western Africa. We propose that an important part of next work in the advancement of bibliodiversity is taking stock at the institutional level where action can be taken. Our hope, then, is that institutional actions will collectively form a true mosaic of intentional and contextualized bibliodiversity.

\section{Bibliography}

Biró, E. (2018). More Than a Facebook Share: Exploring Virtual Linguistic Landscape, Acta Universitatis Sapientiae, Philologica, 10(2), 181-192.

doi: https://doi.org/10.2478/ausp-2018-0022

Chan, L., Okune, A., Hillyer, R., Albornoz, D. \& Posada, A (Eds.). (2019).

Contextualizing Openness: Situating Open Science. University of Ottawa Press. https://ruor.uottawa.ca/handle/10393/39849

Connell, R. (2018). Decolonizing Sociology. Contemporary Sociology, 47(4), 399-407. https://doi.org/10.1177/0094306118779811 
Dacos, M. (2013). La estrategia de la sauna finlandesa. Humanidades Digitales. http://humanidadesdigitales.net/blog/2013/08/12/estrategia-sauna-finlandesa/

Ezema, I. J. \& and Onyancha, O. B. (2016). Status of Africa in the Global Open Access Directories :Implications for Global Visibility of African Scholarly Research. In Sall, E. (Ed.), Fourth CODESRIA Conference on Electronic Publishing. CODESRIA. https://www.codesria.org/spip.php?article2564\&lang $=\mathrm{en} \underline{3}$

Federation of Finnish Learned Societies, Committee for Public Information, Finnish Association for Scholarly Publishing, Universities Norway \& European Network for Research Evaluation in the Social Sciences and the Humanities. (2019). Helsinki Initiative on Multilingualism in Scholarly Communication. https://www.helsinkiinitiative.org/

Fitzpatrick, K. (2011). On Open Access Publishing. https://kfitz.info/on-open-accesspublishing/

Galina, I. (2013). Is There Anybody Out There? Building a Global Digital Humanities Community. Humanidades Digitales.

http://humanidadesdigitales.net/blog/2013/07/19/is-there-anybody-out-there-building-aglobal-digital-humanities-community/

Golumbia, D. (2013). Postcolonial Studies, Digital Humanities, and the Politics of Language. Postcolonial Digital Humanities. https://dhpoco.org/blog/2013/05/31/postcolonial-studies-digital-humanities-and-thepolitics-of-language/

Hathcock, A. (2016). Making the Local Global: The Colonialism of Scholarly Communication. At the Intersection.

https://aprilhathcock.wordpress.com/2016/09/27/making-the-local-global-thecolonialism-of-scholarly-communication/

Henninger, E. (2020). Multilingualism, Neoliberalism, and Language Ideologies in Libraries. In the Library with the Lead Pipe. http://www.inthelibrarywiththeleadpipe.org/2020/multilingualism-in-libraries/ Jussieu Call for Open science and bibliodiversity. (2017). https://jussieucall.org/ Landry, R., \& Bourhis, R. Y. (1997). Linguistic landscape and ethnolinguistic vitality: An empirical study. Journal of Language and Social Psychology, 16(1), 23- 
49. https://doi.org/10.1177/0261927X970161002

Lvković, D. (2012). Virtual Linguistic Landscape: A Perspective on Multilingualism in Cyberspace [Doctoral Dissertation, York University].

Diverse Signatories, (2015). Translation as Research: A Manifesto. Modern Languages Open, None. DOI: http://doi.org/10.3828/mlo.v0i0.80

OPERAS Multilingualism Working Group. (2018). OPERAS Multilingualism White Paper. https://operas.hypotheses.org/aboutoperas/working-groups/multilingualism-wg

Pelak, G. \& Rochen Renner, B. (2020). Helping to Bridge the Communication Gap through Community-Engaged Research Presentations. In Colbert-Lewis, D., Feinstein, E., Mohanty, S. \& Woodbury, D. (Eds.), 2020 TRLN Annual Meeting. Triangle Research Library Network.

Shearer, K., Chan, L., Kuchma, I., \& Mounier, P. (2020). Fostering Bibliodiversity in Scholarly Communications: A Call for Action. https://doi.org/10.5281/ZENODO.3752923

\section{Footnotes}

1. bibliodiversity. (n.d.). Referenced and defined in the International Declaration of Independent Publishers (2014).. \pm

2. It appears the PDF of this article is offline, but Google Scholar has a cached view of it in HTML. $\underline{\Xi}$

3. It appears the PDF of this article is offline, but Google Scholar has a cached view of it in HTML.

\section{Citations}

1. Shearer, K., Chan, L., Kuchma, I., \& Mounier, P. (2020). Fostering Bibliodiversity in Scholarly Communications: A Call for Action. https://doi.org/10.5281/ZENODO.3752923

2. Connell, R. (2018). Decolonizing Sociology. Contemporary Sociology, 47(4), 399407. https://doi.org/10.1177/0094306118779811

3. Chan, L., Okune, A., Hillyer, R., Albornoz, D. \& Posada, A (Eds.). (2019).

Contextualizing Openness: Situating Open Science. University of Ottawa Press. 
https://ruor.uottawa.ca/handle/10393/39849

4. Chan, L., Okune, A., Hillyer, R., Albornoz, D. \& Posada, A (Eds.).

(2019). Contextualizing Openness: Situating Open Science. University of Ottawa Press. https://ruor.uottawa.ca/handle/10393/39849

5. Golumbia, D. (2013). Postcolonial Studies, Digital Humanities, and the Politics of Language. Postcolonial Digital

Humanities. https://dhpoco.org/blog/2013/05/31/postcolonial-studies-digitalhumanities-and-the-politics-of-language/

6.

Galina, I. (2013). Is There Anybody Out There? Building a Global Digital Humanities Community. Humanidades Digitales.

http://humanidadesdigitales.net/blog/2013/07/19/is-there-anybody-out-there-buildinga-global-digital-humanities-community.

$\underline{-}$

7.

Hathcock, A. (2016). Making the Local Global: The Colonialism of Scholarly Communication. At the Intersection.

https://aprilhathcock.wordpress.com/2016/09/27/making-the-local-global-thecolonialism-of-scholarly-communication/

$\underline{-}$

8. Federation of Finnish Learned Societies, Committee for Public Information, Finnish Association for Scholarly Publishing, Universities Norway \& European Network for Research Evaluation in the Social Sciences and the Humanities. (2019). Helsinki Initiative on Multilingualism in Scholarly Communication. https://www.helsinki-initiative.org $L=$

9. Hathcock, A. (2016). Making the Local Global: The Colonialism of Scholarly Communication. At the

Intersection. https://aprilhathcock.wordpress.com/2016/09/27/making-the-localglobal-the-colonialism-of-scholarly-communication/ 
10. Ezema, I. J., \& Onyancha, O. (2016, March). Status of Africa in the global open access directories: Implications for global visibility of African scholarly research. In Fourth CODESRIA conference on electronic publishing: Open Access Movement and the Future of African Knowledge Economy, Dakar, Senegal. $\triangleq$ 11.

Dacos, M. (2013). La estrategia de la sauna finlandesa. Humanidades Digitales. http://humanidadesdigitales.net/blog/2013/08/12/estrategia-sauna-finlandesa/ $\Xi$

12. Landry, R., \& Bourhis, R. Y. (1997). Linguistic landscape and ethnolinguistic vitality: An empirical study. Journal of Language and Social Psychology, 16(1), 2349. https://doi.org/10.1177/0261927X970161002

13. Biró, E. (2018). More Than a Facebook Share: Exploring Virtual Linguistic Landscape, Acta Universitatis Sapientiae, Philologica, 10(2), 181-192. doi: https://doi.org/10.2478/ausp-2018-0022 14.

Lvković, D. (2012). Virtual Linguistic Landscape: A Perspective on Multilingualism in Cyberspace [Doctoral Dissertation, York University].

$\Xi$

15. Diverse Signatories, (2015). Translation as Research: A Manifesto. Modern Languages Open, None. DOI: http://doi.org/10.3828/mlo.v0i0.80

16. Henninger, E. (2020). Multilingualism, Neoliberalism, and Language Ideologies in Libraries. In the Library with the Lead Pipe. http://www.inthelibrarywiththeleadpipe.org/2020/multilingualism-in-libraries/ 17. Pelak, G. \& Rochen Renner, B. (2020). Helping to Bridge the Communication Gap through Community-Engaged Research Presentations. In Colbert-Lewis, D., Feinstein, E., Mohanty, S. \& Woodbury, D. (Eds.), 2020 TRLN Annual Meeting. Triangle Research Library Network. $\subseteq$ 18. 
Fitzpatrick, K. (2011). On Open Access Publishing. https://kfitz.info/on-open-accesspublishing $/$

$\Xi$

19.

Golumbia, D. (2013). Postcolonial Studies, Digital Humanities, and the Politics of Language. Postcolonial Digital Humanities. https://dhpoco.org/blog/2013/05/31/postcolonial-studies-digital-humanities-and-thepolitics-of-language/

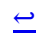

